\title{
Examining Semitic Rhetoric: A Qur'anic Sciences Perspective
}

\author{
Aqdi Rofiq Asnawi, ${ }^{1}$ Idri $^{2}$ \\ ${ }^{1}$ University of Darussalam Gontor Ponorogo, Indonesia \\ ${ }^{2}$ Sunan Ampel State Islamic University Surabaya, Indonesia \\ aqdi.asnawi@unida.gontor.ac.id
}

\begin{tabular}{c}
\hline Article \\
Information \\
\hline
\end{tabular}

Submitted: June 07, 2020

Revised 1: July 07, 2020

Revised 2: October 02, 2020

Accepted: December 18, 2020

\section{Keywords}

Semitic Rhetoric, Michel

Cuypers, Qur'anic

Structure

\section{Kata Kunci}

Semitic Rhetoric, Michel

Cuypers, Struktur Teks

al-Qur'an

\section{Abstract}

In his study of the structure of the al-Qur'an text, Michel Cuypers uses Semitic Rhetoric to analyze the structure of the Biblical text. Despite having received positive responses from Gabriel Said Reynolds and others, Cuypers' method was criticized by Nicolai Sinai for ignoring rhyme in the Qur'an and overdoing in maintaining the existence of the ring structure in the Qur'an. This article will describe the characteristics of this method and the effect it produces, seen from the 'ulûm al-Qur'ân approach using descriptive-analytic and comparative research methods. This study found subjectivity and inconsistencies in the distribution of texts and in determining the structure of their composition, such as in the study of Surah al-Qâri'ah by Cuypers, and the neglect of the history of asbâb al-nuzûl and the Prophet's hadith. However, the application of this method can lead to a new interpretation of the Qur'an, namely by using the information in the Qur'an itself, indicators of wording around it (siyâq), and verse correlation (munâsabât). On the other hand, this method supports the authenticity and coherence of the Qur'anic text, which has become a debate among the Orientalists.

\section{Abstrak}

Dalam kajiannya terhadap struktur teks al-Qur'an, Michel Cuypers menggunakan Semitic Rhetoric untuk menganalisa struktur teks Bibel. Walau telah mendapat respon positif dari Gabriel Said Reynolds dan sarjana lainnya, metode Cuypers dikritisi oleh Nicolai Sinai karena mengabaikan sajak dalam al-Qur'an dan terlalu berlebihan dalam mempertahankan adanya struktur cincin dalam al-Qur'an. Bagaimanakah sebenarnya metode analisa struktur teks ini dilihat dari ilmu-ilmu al-Qur'an ('ulûm al-Qur'ân). Artikel ini akan memaparkan 
karakteristik metode tersebut dan pengaruh yang dihasilkannya dilihat dari pendekatan 'ulûm al-Qur'ân dengan menggunakan metode penelitian deskriptif-analitik dan komparatif. Peneliti menemukan adanya subjektivitas dan inkonsistensi dalam pembagian teks dan penentuan struktur susunannya, seperti pada kajian surah al-Qâri'ah yang dilakukan Cuypers,serta adanya pengabaian riwayat asbâb al-nuzûl dan hadis Nabi. Namun, penerapan metode ini dapat menimbulkan interpretasi baru al-Qur'an yang memiliki keistimewaan dari berbagai sisi, seperti pemanfaatan keterangan dalam al-Qur'an sendiri (tafsîr alQur'ân bi al-Qur'ân), indikator susunan kata di sekelilingnya (siyâq), dan korelasi ayat (munâsabât). Di samping itu, metode ini mendukung autentisitas al-Qur'an dan koherensinya yang selama ini menjadi perdebatan di kalangan Orientalis

\section{Introduction}

The study of the quranic structure has developed in centuries. Initially, it focused on discussing the word order and the style of language used in verse in order to prove the miracles of the Qur'an. ${ }^{1}$ In subsequent developments, the study of the qur'anic structure was on the composition of the verses in a surah. For example, the alZarkashî's (d. 734 AH/1333 CE) discussion on the correlation between verses based on Mushaf Uthmani's order with emphasizing the secret behind the arrangement in the science of occasion ( 'ilm munâsabah). ${ }^{2}$ Al-Biqâ‘î (d. 885 AH) also presented various types of munâsabah verse by verse from surah Fâtihah to surah al-Nâs in his book of tafsitr. ${ }^{3}$ However, the two studies have not found the structure type of the verses' composition in a surah or the al-Qur'an.

In the past century, a different study model of Qur'anic structure emerged. Namely, by dividing the text into several parts to show its coherence

'The model of this study clearly found in: "Ma âny al-Qur' $a ̂ n "$ by al-Farrâ' (d. 207 AH/822 CE), "Majâz al-Qur'ân" by Abu 'Ubaydah (d. 210 AH/825 CE), Bayân I'jâz al-Qur'ân by alKhațâbî (d. 388 AH/998 CE), “Dalâ'il I'jâz” by “Abd al-Qâhir al-Jurjânî (d. 481 AH/1088 CE). See: Faḍl Hasan 'Abbas, I'jâzz al-Qur'ân al-Karîm, $8^{\text {th }}$ ed. (Amman: Dâr al-Nafâis, 2015), 3867.

${ }^{2}$ Badr al-Dîn al-Zarkasyî, al-Burhân fî 'Ulûm al-Qur'ân, Vol. 1 (Beirut: Dâr al-Ma'rifah, 1957), 35-52.

${ }^{3}$ Al-Biqâ‘'î, Nazzmu al-Durar fì Tanâsubi al-Âyât wa al-Suwar (Kairo: Dâr al-Kutub al-Islâmî, n.d.). as was done by Sa'îd Hawwâ (d. 1989 M) ${ }^{4}$ Neal Robinson, ${ }^{5}$ Matthias Zahniser, ${ }^{6}$ Ian Richard Netton, ${ }^{7}$ Raymond Farrin, ${ }^{8}$ and others. Robinson and Zahniser found a mirror composition in alQur'an. At the same decade, Farrin showed a ring composition or concentric composition in surah al-Baqarah, which has similarities with 'amûd al-sûrah, a concept which offered by al-Farâhî (d. 1930 CE) and his student Amîn Ahssan Ișlâhî̂ (d. 1997 CE). ${ }^{9}$ This concept emphasizes the concentration of surah, which lies in a verse or a collection of verses in it. ${ }^{10}$

${ }^{4}$ Sa‘î̀ Hawwâ, Al-Asâs fî al-Tafsîr, $6^{\text {th }}$ ed. Vol. 1, (Kairo: Dâr alSalâm, 1424), 30-31.

${ }^{5}$ Neal Robinson, Discovering the Qur'an: A Contemporary Approach to a Veiled Text (London: SCM Press, 1996); Neal Robinson, "The Structure and Interpretation of Sūrat alMu'minūn," Journal of Qur'anic Studies 2, no. 1 (2000): 89106; Neal Robinson, "Hands Outstretched: Towards a Rereading of Sūrat al-Mā' ida," Journal of Qur'anic Studies 3, no. 1 (2001): 1-19; Neal Robinson, "Sūrat Āl 'Imrān and Those with the Greatest Claim to Abraham," Journal of Qur'anic Studies 6, no. 2 (2004): 1-21.

${ }^{6}$ Matthias Zahniser, "Major Transitions and Thematic Borders in Two Long Sūras: Al-Baqara and al-Nisa'," in Literary Structures of Religious Meaning, ed. Issa Boullata (Richmond: Curzon Press, 2000), 22-55.

${ }^{7}$ Ian Richard Netton, "Towards a Modern Tafsir of Surah alKahf: Structure and Semiotics," Journal of Qur'anic Studies 2, no. 1 (2000): 67-87.

${ }^{8}$ Raymond Farrin, Structure and Qur'anic Interpretation: A Study of Symmetry and Coherence in Islam's Holy Text (Ashland, Oregon: White Cloud Press, 2014).

${ }^{9}$ Aqdi Rofiq Asnawi, "Penerapan Semitic Rhetoric Analysis (SRA) pada Surah al-Qiyâmah," Mutawatir: Jurnal Keilmuan Tafsir Hadith 8, no. 1 (2018): 145.

${ }^{10}$ Mustansir Mir, Coherence in the Qur'ân. A Study of Islâhî's 
On the other side, Michel Cuypers showed a mirror, concentric (ring) and parallel composition in the Qur' an using Semitic Rhetoric's principles. ${ }^{11}$ According to Gabriel Said Reynolds, Cuypers' method offers a new model in the study of qur'anic structure that combines critical thinking, interpretive literature, and the contents of the Bible. ${ }^{12}$ Meanwhile, Anne-Sylvie Boisliveau has considered it a proven method of studying the Bible and the Qur'an objectively, not just an ideological transposition of some elements of Biblical exegesis on the interpretation of the Qur'an. ${ }^{13}$ Besides, Halla Attallah believed it a valuable theoretical approach in the field of alQur'an studies. The analysis system offered is beneficial for anyone who analyzes the Qur'an using a structuralism linguistic approach. ${ }^{14}$ Adnane Mokrani introduced the Cuypers approach with the term 'Semitic Rhetorical Analysis (SRA)'. He also called it a modern methodology representing a new type of dialogue, namely methodological dialogue between Biblical studies and Qur'anic studies. ${ }^{15}$

Although it took positive responses from some scholars, the Cuypers method received sharp criticism from Nicolai Sinai. In his observation, Sinai viewed Cuypers excessive in defending his thesis that there is a ring structure in the Qur'an. According to Sinai, Cuypers has arbitrarily partitioned the verses and deliberately ignored the urgency of the poetry in the Qur'an to support

Concept of Nażm in Taddabur-i Qur 'ân (Indianapolis: American Trust Publications, 1986), 38-39.

${ }^{11}$ Michel Cuypers, "Semitic Rhetoric as a Key to the Question of the Nazm of the Qur'anic Text," Journal of Qur'anic Studies 13, no. 1 (2011): 4.

${ }^{12}$ Gabriel Said Reynolds, "Buchbesprechungen," Der Islam 88, no. 2 (2012): 427-434.

${ }^{13}$ Anne-Sylvie Boisliveau, "Reviewed Work: Le Festin: Une lecture de la sourate al-Mâ'ida by Michel Cuypers," Journal of Qur'anic Studies 9, no. 1 (2007): 119-23.

${ }^{14}$ Halla Attallah, "Michel Cuypers, The Composition of the Qur'an: Rhetorical Analysis, translated by Jerry Ryan. LondonNew York: Bloomsbury Academic, 2015," Der Islam 95, no. 1 (2018): 211-17.

${ }^{15}$ Adnane Mokrani, "Semitic Rhetoric and the Qur'ān: The Scholarship of Michel Cuypers," New Trends in Qur'anic Studies: Text, Context, and Interpretation, ed. Mun'im Sirry (Atlanta, Georgia: Lockwood Press, 2019), 61-81. his thesis. Also, Cuypers has argued against two kinds of rhetoric: Greek rhetoric and Semitic rhetoric, which seem to have been influenced by racist theories and 19th-century cultural differentiation. ${ }^{16}$

Based on the academic debate above, this article seeks to present a perspective on how the methodological characteristics of the Semitic Rhetoric in the perspective of the sciences of the Qur'an ( 'ulum al-Qur'ân) by using the descriptive analysis method as well as comparative.

The sciences of the Qur'an in question involve various discussions in the science of munâsabah, the science of interpretation (tafsîr), and the authenticity of the Qur'anic text. ${ }^{17}$ To the best of the author's knowledge, no scholar has adopted this perspective to analyze Cuypers' method; it could produce a different perspective from previous studies. Besides, it is essential to examine Cuypers' approach in the qur'anic sciences perspective to provide a methodological guide for scholars to improve it and apply it in their studies about qur'anic structure with attention to its influences impacts.

\section{Biography of Michel Cuypers and His Works in Qur'anic Studies}

Born in 1941, Michel Cuypers is from Belgium, lived in Iran for 12 years and even earned his doctoral degree from the University of Tehran in Persian Literature. Currently, he lives in Hagaza, a small town adjacent to Luxor, Egypt. He works as a researcher at the Dominicain d'Études Orientales Institute (IDÉO), a centre for oriental studies based in Cairo, Egypt. He is also a member of the association Fraternity of the Little Brothers of Jesus, a fraternity of the

\footnotetext{
${ }^{16}$ Nicolai Sinai, "Review Essay: 'Going Round in Circles': Michel Cuypers, The Composition of the Qur'an: Rhetorical Analysis, and Raymond Farrin, Structure and Qur'anic Interpretation: A Study of Symmetry and Coherence in Islam's Holy Text," Journal of Qur'anic Studies 19, no. 2 (2017): 106-122.

${ }^{17}$ Discussions about the sciences of the Qur'an can be found in books of 'ulûm al-Qur'ân, for example: al-Burhân by alZarkasyî, al-Itqân by al-Suyûtîi, Manâhil al- 'Irfân by al-Zurqânî, Mabahith fì 'Ulûm al-Qur'ân by Manna' al-Qațân, and so on.
} 
Catholic Church whose teachings are inspired by Charles de Foucauld. ${ }^{18}$

Apart from writing articles in various international journals, ${ }^{19}$ Cuypers has published three books on the Qur'an. His first book is entitled "Le Festin: Une lecture de la sourate al-Mâ'ida."20 In this book, Cuypers applied Semitic Rhetoric (al-Balâghah al-Sâmiyah) principles to surah alMâ'idah.

Further information about Semitic Rhetoric and its application in the al-Qur'an he explained in his second book. ${ }^{21}$ His third book discusses the structure of the last 33 chapters in the Qur'an based on Semitic Rhetoric theory. ${ }^{22}$

The explanation above indicates that Michel Cuypers is an orientalist in the sense of Westerners who study languages, science, culture, history, and customs in Eastern countries. ${ }^{23}$ However, this term also applied to anyone who studies the East (Islam) based on logic, ontology, and Western epistemology, regardless of whether he is Westerner or not. ${ }^{24}$ Cuypers is appropriate

\footnotetext{
18"Michel Cuypers, P.F.J.," obtained from https://www.ideocairo.org/en/michel-cuypers-p-f-j-2/; Internet; accessed on 24 February 2020.

${ }^{19}$ For example: « Le Coran relève d'une rhétorique sémitique commune avec la Bible », Philosophie magazine, hors-série «Le Coran ", 2010, pages 88-89; "Semitic rhetoric in the Koran and a Pharaonic papyrus," US-China foreign Language 76, January 2010, 8-13; "Semitic rhetoric as a key to the question of the nazm (composition) of the Qur'an, Journal of Qur'anic Studies, 2011. ${ }^{20}$ Michel Cuypers, Le Festin. Une lecture de la sourate alMâ'ida (Paris: Lethielleux, 2007), which in English edition under the title The Banquet: A Reading of the Fifth Sura of the Qur'an (Florida: Convivium Press, 2009). 'Amr Abd al-'Âṭ̂ Sâlih has translated it into Arabic under the title Fî Nażmi Sûrati al-Mâ'idah: Nażmu Âyi al-Qur'ân fị Daw'i Manhaji al-Tahlîl alBalâghî (Beirut: Dâr al-Masyriq, 2016).

${ }^{21}$ Michel Cuypers, La Composition du Coran. Nazmu al-Qur'ân (Paris: Gabalda, 2012). Three years later, the English edition appeared with the title The Composition of the Qur'an, Rhetorical Analysis (London: Bloomsbury Academic, 2015). In 2018, an Arabic edition of the book entitled Fî Nazm al-Qur'ân (Beirut: Dâr al-Masyriq, 2018). ${ }^{22} \mathrm{Michel}$ Cuypers, Une apocalypse coranique. Une lecture des trente-trois dernières sourates $d u$ Coran. In its English translation, the book is entitled A Qur'anic Apocalypse: A Reading of the Thirty-three Last Surrahs of the Qur'ân.

${ }^{23}$ Muhammad Husain, al-Mustasyriqûn wa al-Dirâsât alQur'âniyyah (Beirut: Dâr al-Muarrikh al-'Arabiy, 1999), 11 .

${ }^{24}$ Idri, Hadis dan Orientalis (Depok: Kencana, 2017), 2.
}

called orientalist since he focuses on studying the structure of the text of the Qur'an using the perspective of Semitic Rhetoric, which incidentally comes from the Western academia. ${ }^{25}$

\section{Michel Cuypers' Approach in Studying the Structure of al-Qur'an Text}

\section{Basic Principles of Semitic Rhetoric Analysis (SRA)}

According to Cuypers, rhetoric is 'the art of composition of speech' or 'the arrangement of the parts of speech'. A text is structured based on Semitic Rhetoric when there is a series of symmetrical arrangements at various textual levels. ${ }^{26}$ There are three forms of symmetry or figures of composition:

a. Parallelism, or parallel construction, where related units of text reappear in the same order $\left(\mathrm{ABC} / \mathrm{A}^{\prime} \mathrm{B}^{\prime} \mathrm{C}^{\prime}\right),{ }^{27}$ such in surah al-Inshiqâq (84) verses 7-12:

\begin{tabular}{|c|c|}
\hline A & $\begin{array}{r}\text { 7. Then whoever is given his } \\
\text { book in his right hand, } \\
\text { B }\end{array}$ \\
& $\begin{array}{r}\text { Will be reckoned } \\
\text { with by an easy } \\
\text { reckoning, } \\
\text { 9. And shall } \\
\text { go back to } \\
\text { his people } \\
\text { joyfully. }\end{array}$ \\
\hline 'A & $\begin{array}{r}\text { 10. But whoever is given his } \\
\text { book behind his back, } \\
\text { 11. He shall call for } \\
\text { 'B }\end{array}$ \\
' $\mathrm{C}$ & $\begin{array}{r}\text { 12. And shall burn } \\
\text { in a blazing- } \\
\text { fire. }{ }^{28}\end{array}$ \\
\hline
\end{tabular}

\footnotetext{
${ }^{25}$ Michel Cuypers, "Semitic Rhetoric as a Key to the Question of the Nazm of the Qur'anic Text," Journal of Qur'anic Studies 13, no. 1 (2011), 2-4.

${ }^{26}$ Ibid.

${ }^{27}$ Ibid.; Roland Meynet, Treatise on Biblical Rhetoric, translated from France by Leo Arnold (Leiden and Boston: Brill, 2012), 72. ${ }^{28}$ Michel Cuypers, The Composition of the Qur'an; Rhetorical Analysis, transl. Jerry Ryan (London: Bloomsbury Academic, 2015), 30.
} 
b. Ring or concentric composition, when the units of text are arranged concentrically around a centre $\left(\mathrm{ABC} / \mathrm{x} / \mathrm{C}^{\prime} \mathrm{B}^{\prime} \mathrm{A}\right.$ '), but sometimes merely (A/x/A'), ${ }^{29}$ such in surah al-Quraysh (106):

\begin{tabular}{|c|c|}
\hline $\mathrm{A}$ & $\begin{array}{c}\text { 1. For the covenant } \text { of Quraysh, } \\
\text { 2. Their covenant for their winter } \\
\text { and summer journeys, }\end{array}$ \\
\hline $\mathrm{X}$ & $\begin{array}{l}\text { 3. Let them adore the } \\
\text { Lord of this House, }\end{array}$ \\
\hline 'A & $\begin{array}{l}\text { 4. Who feeds them against } \\
\text { famine and secures them } \\
\text { from fear. }\end{array}$ \\
\hline
\end{tabular}

c. Mirror composition, when the central element is missing, but the relationship between parts of the text still exists like a mirror $(\mathrm{ABC} /$ C'B'A'). ${ }^{31}$ For example, in surah al-Muṭaffifîn (83) verses 4-6:

\begin{tabular}{|c|c|}
\hline A & $\begin{array}{l}\text { 4. Do they not think, THESE } \\
\text { [PEOPLE] }\end{array}$ \\
B & That they will be raised up \\
C & 5.For a mighty day, \\
\hline 'C & 6.A day \\
'B & when will rise \\
'A & $\begin{array}{l}\text { THE PEOPLE to the Lord of } \\
\text { the worlds? }\end{array}$ \\
\hline
\end{tabular}

Symmetry in the text emerged for the relation of pairs of text sections at various levels. The relationship between a part of the text and its pair can be repetition, similarity, description, causeeffect relationship, time sequence, antonymy, and other indications. ${ }^{33}$

\footnotetext{
${ }^{29}$ Michel Cuypers, The Composition of the Qur'an; Rhetorical Analysis, transl. Jerry Ryan (London: Bloomsbury Academic, 2015), 30.

${ }^{30}$ Mary Douglas, Thinking in Circles: An Essay on Ring Composition (New Haven and London: Yale University Press, 2007), 6-7; Michel Cuypers, "Semitic Rhetoric as a Key ...", 4. ${ }^{31}$ Michel Cuypers, The Composition of the Qur'an ..., 85.

${ }^{32}$ Roland Meynet, Rhetorical Analysis: An Introduction to Biblical Rhetoric (Sheffield: Sheffield Academic Press, 1998), 217; Mary Douglas, Thinking in Circles, 6-7; Roland Meynet, Treatise on Biblical Rhetoric, 72; Michel Cuypers, "Semitic Rhetoric as a Key ...", 4.

${ }^{33}$ Michel Cuypers, The Composition of the Qur'an ..., 85.
}

These indicators and symmetrical composition exist at all levels of text, from lower levels (smaller sections) to higher levels (larger parts) provided that some of the smaller parts must be a larger part above it. The following are the names of the part of the text in the Semitic Rhetoric:

1. Member (mafșil) consists of several words that indicate a specific purpose;

2. Segment (far 'u), consists of a maximum of three members;

3. Piece (qism), consists of a maximum of three segments;

4. Part (juz), consists of a maximum of three pieces;

5. Passage (maqta '), consists of one or more parts;

6. Sequence (silsilah), consists of one or more passages;

7. Section (syu'bah), consists of one or more sequences;

8. Book (kitâb), consists of one or more sections. ${ }^{34}$

Based on the principles above, the text's composition consists of several parts that form a certain symmetry. The method to study it starts from dividing the text into several parts, from the smallest part to the largest part text (several parts at a text level must form a part at the level above it) and then determining the symmetrical construction formed by the sections of the text at any level. That may distinguish Semitic Rhetoric from other method analysis of the text.

\section{Application of Semitic Rhetoric Analysis (SRA) in Qur'anic Studies}

According to Cuypers, principles of composition in Semitic Rhetoric existed in Qur'an, just like the Bible in Hebrew, ${ }^{35}$ since Arabic - the language used in the Qur'an - and Hebrew are both belong to the Semitic language family, ${ }^{36}$ making al-Qur'an

\footnotetext{
${ }^{34}$ Michel Cuypers, Fî Nazmi al-Qur'ân, 18, 85; Michel Cuypers, "Semitic Rhetoric as a Key..., 4.

${ }^{35}$ Michel Cuypers, "Semitic Rhetoric as a Key..., 2.

${ }^{36}$ Ibid., 2-4; Israel Wolfensohn, Târikh al-Lughât al-Sâmiyyah (Beirut: Dâr al-Qalam, 2016), 13.
} 
and Bible appropriate to tread equally.

Cuypers applied this method analysison the surah al-Qâri'ah (101) in his two separate works: Fî Nazmi al-Qur'ân and Semitic Rhetoric as a Key to the Question of the Nazm of the Qur'anic Text. In his former work, he has considered this surah to be a passage consisting of two parts, and each part consisting of two pieces. Each piece consists of two segments. The number of members in each segment is uncertain; some are one member, some are two, and some are three. The following table describes in more detail the composition of the surah al-Qâri'ah:

\begin{tabular}{|c|l|}
\hline Member & \multicolumn{1}{|c|}{ Qur'anic Text } \\
\hline 1 & 1. The Striking! \\
\hline 2 & 2. What is the Striking? \\
\hline $3 \mathrm{a}$ & $\begin{array}{l}\text { 3. And what will let you } \\
\text { know }\end{array}$ \\
\hline $3 \mathrm{~b}$ & what is the Striking? \\
\hline $4 \mathrm{a}$ & $\begin{array}{l}4 . \text { The day on which will } \\
\text { be men }\end{array}$ \\
\hline $4 \mathrm{~b}$ & as moths scattered, \\
\hline $5 \mathrm{a}$ & $\begin{array}{l}5 . \text { And will be the } \\
\text { mountains }\end{array}$ \\
\hline $5 \mathrm{~b}$ & as wool carded. \\
\hline 6 & $\begin{array}{l}6 . \text { Then as for him whose } \\
\text { balances are heavy, }\end{array}$ \\
\hline 7 & $\begin{array}{l}7 . \text { He [will be }] \text { in a } \\
\text { pleasant life. }\end{array}$ \\
\hline 8 & $\begin{array}{l}8 . \text { And as for him whose } \\
\text { balances are light, }\end{array}$ \\
\hline 9 & $\begin{array}{l}9 . \text { Then the place of return } \\
\text { is Hawiyah.. }\end{array}$ \\
\hline $10 \mathrm{a}$ & $\begin{array}{l}10 . \text { And what will let you } \\
\text { know }\end{array}$ \\
\hline 11 & $\begin{array}{l}\text { what is it? } \\
11 . \text { A blazing fire! }\end{array}$ \\
\hline
\end{tabular}

In the composition above, the surah al-Qâri'ah consists of 15 members. However, in other work, he divided the surah into nine members. Verse 4,

\footnotetext{
${ }^{37}$ Michel Cuypers, The Composition of the Qur'an ..., 29.

${ }^{38}$ Michel Cuypers, "Semitic Rhetoric as a Key ...", 7-8.
}

which initially consists of two members, becomes one member, so does verse5. Meanwhile, verses 6 and 7 become into one member as verses 8 and $9 .^{38}$

Although they have different divisions, both have the same construction pattern, namely mirror composition (AB/B'A') at the part level. ${ }^{39}$ Thus surah al-Qâri'ah has a specific construction pattern and consists of interrelated verses. Cuypers used this result to refute Richard Bell, who stated that the authenticity of verses 6-9 in this surah is doubtful, added later, or relocated from surah al-Hâaqah(69). ${ }^{40}$ According to Bell, the last verse of this surah was probably added by the Prophet Muhammad or left behind by accident. ${ }^{41}$ Cuypers opposed this skeptical statement with his approach to the structure of the Qur'an. ${ }^{42}$

\section{Reasons and Objectives for Application of Semitic Rhetoric Analysis (SRA)}

Apart from the fact that the language of the Qur'anic and the Biblical language originates from the Semitic language family, ${ }^{43}$ the reason for applying SRA is the previous studies of Qur'anic structure did not use a suitable method for analyzing Qur'anic text. ${ }^{44}$ Cuypers has strengthened his argument based on two things:

Greek rhetorical logic appeared earlier in the study of Qur'anic structure, such in the discussion of the relationship between verses in the science of munasabah. Whereas Greek Rhetoric is different from Semitic Rhetoric, if the former tends to be the art of expressing beautiful expressions or beautifying words, the latter tends to be the art of speech composition.

Previous rhetorical research has only focused on studying rhetorical pictures, such as majâz, isti'ârah, tasybîh, and so on in a sentence. However,

\footnotetext{
${ }^{39}$ Ibid., 9.

${ }^{40}$ In verse 4 with the word al-Qâri'ah inside.

${ }^{41}$ Richard Bell, The Qur'ân: Translated, with a critical rearrangement of the Surahs (Edinburgh: T. \& T. Clark, 1939), 674.

${ }^{42}$ Michel Cuypers, "Semitic Rhetoric as a Key ...", 7-9.

${ }^{43}$ Ibid., 2-4.

${ }^{44}$ Michel Cuypers, Fî Nazmi Sûrati al-Mâ'idah..., 22.

${ }^{45}$ Ibid., 25.
} 
there has been no discussion on a comprehensive picture of the text's structure, except for what Saîd Hawa dan Amin Ahsan al-Ișlâhi did. ${ }^{45}$

Therefore, Cuypers applied SRA in the study of the Qur'an in order to offer a new method that has clear principles and rules in studying the structure of the Qur'anic text. ${ }^{46}$ The aim also to understand the Qur'anic messages correctly and away from subjectivity since Cuypers claims SRA is a method that examines in detail every verse and sentence, away from what its predecessors methodology. ${ }^{47}$

Through this approach, Cuypers also wants to improve the spreading hypothesis or assumption among Western academics that the Qur'an has no systematic composition, and there is no unity or attachment between parts of the text. ${ }^{48}$ Besides, to build good communication between Muslims and Christians through the exchange of Biblical understanding. ${ }^{49}$

\section{The influence of Semitic Rhetoric in Qur'anic Studies}

This new approach brought "good news" for Qur'anic researchers, since its influence, at least in terms of interpretation and authenticity of the Qur'an. This approach has the potential to produce a new qur'anic interpretation and supports the authenticity of the Qur'an.

a. Semitic Rhetoric Influence on Qur'anic Interpretation

The symmetrical composition in Semitic Rhetoric makes a part of the text pair with another part. In concentric composition, the relationship between parts of the text also comes from the central part's relationship to

\footnotetext{
${ }^{46}$ Michel Cuypers, Fî Nazmi al-Qur’ân, 5.

${ }^{47}$ Ibid., 7 and 201; Michel Cuypers, Fî Nazmi Sûrati al-Mâ'idah, 493.

${ }^{48}$ Michel Cuypers, Fî Nazmi al-Qur'ân, 8.

${ }^{49}$ Ibid., 8. See also: Muhammad Yaslam al-Mujawwad, "Manhaj al-Balâghah al-Sâmiyah fi Dirâsah Bunyat al-Qur'ân alKarîm," https://tafsir.net/research/41/mnhj-al-blaght-as-samyyt-fy-drast-bnyt-al-qr-aan-al-krym-drast-wsfyt-nqdyh; Internet; accessed on 24 February 2020.
}

every other part. This relationship emerges from the lexical and grammatical meaning of words for word. However, it has developed further so that the various relationships can lead to other meanings, even new interpretations of a verse. Thus, this method has the potential to produce a different interpretation than before.

However, Cuypers did not explain all the verses in this approach. In some of his works, he only emphasized Qur'anic structure by giving the title to a collection of parts of the text without interpreting the al-Qur'an verse by verse. Even so, he acknowledged that the best possible interpretation of the al-Qur'an from this approach would emerge. ${ }^{50}$

For example, the interpretation of surah al-'Alaq (96) verse 1. According to Cuypers, the word iqra' in this verse does not indicate a prophetic mission's investiture as tafsir scholars has interpreted it. However, he interpreted that word as a call to prayer because of verse 1 paired with the last verse containing the word iqtarib, which form a paronomasia (paronomase): iqra' dan iqtarib..$^{51}$ This conclusion came after Cuypers analyzed the structure of surah al-'Alaq. He divided the surah into sections and determined that its symmetrical composition. The following table shows the whole structure of surah:

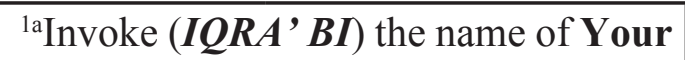
Lord $^{\mathrm{b}}$ who created, ${ }^{2}$ created man from aclot. ${ }^{3}$ Invoke, for Your Lord is the Most Generous ${ }^{4}$ who taught by the pen, ${ }^{5}$ taught MAN what HE DID NOT KNOW (LAM YA' $L A M)$

\footnotetext{
${ }^{50}$ Michel Cuypers, Fî Nazmi al-Qur'ân, 201.

${ }^{51}$ Michel Cuypers, The Composition of the Qur'an ..., 165.
} 


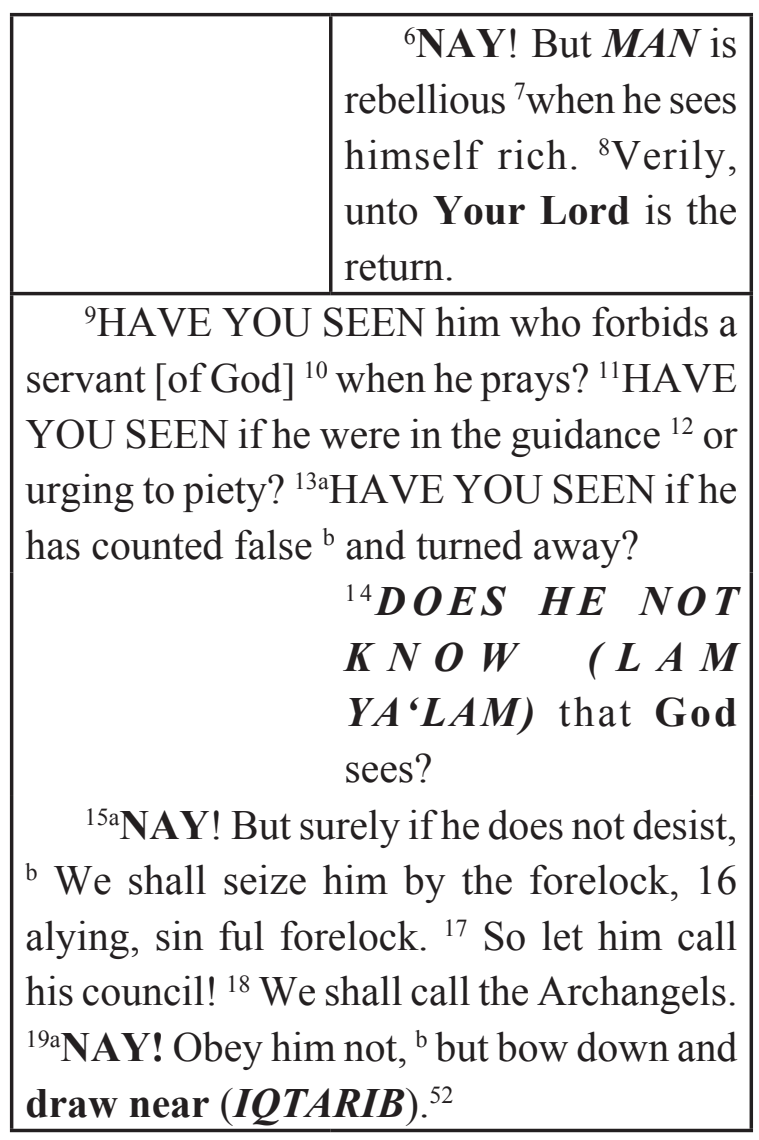

This structure of the surah al-'Alaq shows a concentric symmetry composition, so the first and last member verses of this surah are connected, especially in the first element (iqra') and the last element (iqtarib). Apart from being both in command form, they both sound pretty much the same. Thus, according to Cuypers, they both show the same meaning, namely the call to prayer. ${ }^{53}$

This interpretation is different from other interpretations of surah al-'Alaq this one verse. Muslim scholars interpreted this verse as a call to read, that is, reading the Qur'an, the revelation to the Prophet Muhammad, as well as showing the first verse revealed of the Qur'an. ${ }^{54}$

${ }^{52}$ Ibid., 166.

${ }^{53}$ Michel Cuypers, Fî Nazmi al-Qur'ân, 213.

${ }^{54}$ Fakhr al-Dîn al-Râzî, Mafâtîh al-Ghayb, 3th ed., vol. 32 (Beirut: Dâr Ihyâ' al-Turâth al-'Arabî, 1420), 215; Al-Biqâ‘̂̂, Nazmu alDurar fi Tanâsubi al-Âyât wa al-Suwar, vol. 22 (Kairo: Dâr alKutub al-Islâmî, n.d.), 152; Ibnu 'Âsyûr, al-Tahrîr wa al-Tanwîr, vol. 30 (Tunis: al-Dâr al-Tûnisiyyah li al-Nasyr, 1984), 436.
Another example is the interpretation of surah al-Bayyinah (98) verse 5 and verse 8 . Because the text structure of this verse forms a parallel symmetrical pattern, Cuypers argues that what is meant by dîn al-qayyimah (the true religion) in verse 5 is dîn man khashiya rabbah (the religion of those who fear their Lord) in verse $8 .{ }^{55}$ The following is the structure of the surah al-Bayyinah according to Cuypers:

\begin{tabular}{|c|c|}
\hline Piece & Verses \\
\hline A & $\begin{array}{l}{ }^{1} \text { Those who disbelieve from among the } \\
\text { People of the Book and the } \\
\text { Polytheists were not set free [from their } \\
\text { observances] until after the clear Proof } \\
\text { came to them, }{ }^{2} \text { a Messenger from God } \\
\text { who recites pure sheets, }{ }^{3} \text { in which are } \\
\text { true Books. }\end{array}$ \\
\hline B & $\begin{array}{l}{ }^{4} \text { Those that have been given the Book } \\
\text { did not become divided until there had } \\
\text { come to them the Proof. }{ }^{5} \text { And they have } \\
\text { merely been commanded to worship } \\
\text { God, purifying religion for Him, as } \\
\text { righteous believers, and to keep up the } \\
\text { prayer and to pay the prescribed alms. } \\
\text { That is the true religion. }\end{array}$ \\
\hline 'A & $\begin{array}{l}{ }^{6} \text { Verily, those who disbelieve from } \\
\text { among the People of the Book and the } \\
\text { Polytheists, shall be in the fire of the } \\
\text { Hell, abiding therein: they are the worst } \\
\text { of creation. }\end{array}$ \\
\hline${ }^{\prime} \mathrm{B}$ & $\begin{array}{l}{ }^{7} \text { Verily, those who believe and do good } \\
\text { deeds are the best of creation. }{ }^{8} \text { Their } \\
\text { reward with their Lord will be the } \\
\text { gardens of Eden beneath which rivers } \\
\text { flow, abiding therein forever. God shall } \\
\text { be pleased with them and they shall be } \\
\text { pleased with Him. } \\
\text { That is for him who fears his Lord. }\end{array}$ \\
\hline
\end{tabular}

After dividing the surah to several parts,

\footnotetext{
${ }^{55}$ Michel Cuypers, The Composition of the Qur'an ..., 72; Michel Cuypers, Fî Nazmi al-Qur'ân, 97.
} 
Cuypers considered surah al-Bayyinah is a passage with two parts, and every part has two pieces. The symmetric composition of this surah is parallel composition (AB/A'B'), since piece 1 (verses $1-3$ ) is pairing with piece 3 (verse 6), and piece 2 (verses 4-5) is pairing with piece 4 (verses 7-8). Therefore, verse 1 is similar to the beginning of verse 6 in terms of discussion about unbelievers. Then he interpreted the end of verse 5, dîn al-qayyimah (the true religion), by the end of verse 8, dîn man khashiya rabbah (the religion of those who fear their Lord). ${ }^{56}$

So far there has not been any Muslim scholars who interpreted dîn al-qayyimah as the meaning of dîn man khashiya rabbah. Fakhr al-Râzî interpreted it as "a religion that is clear, straight, and moderate". ${ }^{57} \mathrm{Al}$-Biqâa $\hat{1}$ stated that the religion in question is "a religion that has no deviations (lâ 'iwaja fihâ)," ${ }^{58}$ while Ibn 'Âsyûr interpreted it as "the religion of the prophets and pious people". ${ }^{59}$ Cuypers should be the first person to interpret it as "the religion of people who fear their God".

\section{b. Semitic Rhetoric's Influence on the Authenticity} of the Qur'an in Orientalists Perspective

In his study, Cuypers elaborated various verses and chapters according to the order in the mushaf. He did not question the order of the verses or the surahs in the Qur'an, let alone state that there were additional texts that were not supposed to be in it. Indirectly, he acknowledged the authenticity of the Qur'an and the consistency of its composition since its time of revelation.

This point of view is different from other orientalist views, such as Richard Bell. He doubted the authenticity of the Qur'an and

${ }^{56}$ Ibid.

${ }^{57}$ Fakhr al-Dîn al-Râzî, Vol. 32, 245.

${ }^{58}$ Al-Biqâ‘î̀, Vol. 22, 195

${ }^{59}$ Ibnu 'Âsyûr, Vol. 30, 481.

${ }^{60}$ Michel Cuypers," Semitic Rhetoric as a Key ...", 9. stated that some verses were in the wrong order. For example, in surah al-Qâri'ah as previously explained in this article. Through the Semitic Rhetoric Analysis approach, Cuypers refuted Bell's opinion about the composition of the surah al-Qâri' ah. ${ }^{60}$

Cuypers has also proven the relationship between the passages of the Qur'anic text and their order patterns. That study contradicts the opinion of some orientalists, such as J. M. Rodwell, who considered Zaid bin Thabit randomly sequenced Qur'anic verses and carelessly when collecting the Qur'an in the musaf. In other words, he collected the Qur'an regardless of the chronological order in which the al-Qur'an descended so that there is no coherence between qur'anic text. ${ }^{61}$ According to Cuypers' study, this assumption is wrong since that study proved the relationship between the verses and a particular pattern in its arrangement.

Cuypers' discussion on qur'anic structure is also inseparable from the word's lexical meaning in Arabic. He applied Semitic Rhetoric due to his belief that the Qur'an was revealed and written in Arabic, not other languages. Meanwhile, other orientalists, such as Arthur Jeffery, ${ }^{62}$ Andrew Rippin, and Michael Cook, tried to analyze qur'anic vocabularies based on its etymology in other languages, which criticized the earlier exegesis works. Some studies showed many mistakes in their efforts. ${ }^{63}$ According to Toshihiko Izutsu, such etymological studies

${ }^{61}$ J. M. Rodwell, The Koran (New York: Dover Publication, 2005), 2.

${ }^{62}$ Arthur Jeffery has compiled qur'anic vocabularies which he considered non-Arabic in his book: The Foreign Vocabulary of The Qur'an (Baroda: Oriental Institute, 1938).

${ }^{63}$ Walid Saleh, "The Etymological Fallacy and Qur'anic Studies: Muhammad, Paradise, and Late Antiquity," in The Qur'an in Context, ed. Angelika Neuwirth, Nicolai Sinai, Michael Marx (Leiden: Brill, 2010), 651-652.

${ }^{64}$ Toshihiko Izutsu, God and Man in the Qur'an: Semantics of the Qur'anic Weltanschauung (Petaling Jaya: Islamic Book Trust, 2008), 17. 
are not valid in vocabulary studies because they are only based on estimates and often lead to unsolved puzzles. ${ }^{64}$

Therefore, Cuypers' approach overthrew previous orientalist theories that doubted the authenticity of the Qur'an, let alone the growing assumption that the Qur'an was not structured systematically. Interestingly, the approach he has used has been applied to the Bible by Western academics.

\section{Criticism of Cuypers Approach to Study Qur'anic Structure}

\section{Criticism of Theory and Its Application}

Compared to other text structure approaches, Cuypers' approach using Semitic Rhetoric Analysis is more systematic since there are exact steps in its application. The aim of this approach can also be said to be 'noble' because it wants to make relations between religions more harmonious, prove the authenticity of the Qur'an, and so on.

Despite its many advantages, Cuypers' theory in the structure of the Qur'an is weak on various sides. First, there is no complete formula on how to classify words into the smallest piece of text called a member, likewise, in the arrangement of sections of the text at a higher level. Cuypers himself has two opinions on the division of the surah al-Qâri'ah, as explained above.

Second, the grouping of the words of the Qur'an in this method makes the verse cut into several parts. As a result, the meaning of the full verse cannot appear ultimately.

Third, the search for relationships between parts of the text to form a symmetrical composition tends to be like the process of releasing part of a verse to match a part in another verse based on reasons that seem forced. Even Cuypers himself shows his inconsistency in sharing the surah of al-Qâri'ah. Therefore, the Cuypers method gives the applicator the freedom to determine the symmetrical composition to reduce the objectivity of this study. Likewise, these findings indicate that Cuypers' failure to achieve his approach's goal, which is to offer a consistent approach and far from subjectivity.

Fourth, Cuypers' methodology in studying the Qur'an is one of the methods to study the Bible in Western academia. Unfortunately, Cuypers did not mention the advantages and disadvantages of applying this theory to the Bible. This discussion affects the urgency of its application to the Qur'an. If it has many deficiencies in Biblical studies, it is possible that the same deficiencies also arise in the study of the Qur'an.

Fifth, Cuypers did not apply Semitic Rhetorical Analysis to all surahs in the al-Qur'an, so he should not conclude that the al-Qur'an was composed based on Semitic Rhetoric.

Sixth, Cuypers is less observant in assessing previous research on the qur'anic structure. He stated that the previous approach failed in analyzing the structure of the Qur'anic text, which consists of three types of symmetrical construction patterns: parallel, concentric, and mirror. However, these symmetrical construction shave commonalities with al-Farâhî's (d. 1930 CE) concepts of Qur'anic structure. The parallel composition is similar to what al-Farâhi called alLaff wa al-Nashr and the concentric arrangement as al-I'tirâd, while the mirror arrangement is called al-'Aud ilâ al-Bad'. ${ }^{65}$ Cuypers should present previous academic studies in more depth and not rule out al-Farâhî terms which are similar to the construction pattern in his approach. However, this similarity does not interfere with the authenticity of Cuypers' approach because two people may have the same opinion in assessing the composition of the Qur'anic text.

\section{Criticism of Cuypers' Interpretation}

Based on 'ulûm al-Qur'ân, the interpretation

\footnotetext{
${ }^{65}$ Muhammad Yaslam al-Mujawwad, "Manhaj al-Balâghah alSâmiyah fi Dirâsah Bunyat al-Qur'ân al-Karîm,” https://tafsir. net/research/41/mnhj-al-blaght-as-samy-yt-fy-drast-bnyt-alqr-aan-al-krym-drast-wsfyt-nqdyh; Internet;accessed on 24 February 2020.
} 
offered by Cuypers, like interpreting surah al'Alaq verse 1 on the word "iqra!" as a call to prayer, is not a proper interpretation since it ignores asbâb al-nuzûl, the hadith of the Prophet, and the etymological meaning. These three elements are the primary sources in the process of interpreting the Qur'an. ${ }^{66}$

For example, in iqra's interpretation, Aishah narrated that Jibril came to the Prophet in the cave of Hira' who was worshipping and Jibril said: iqra'! Then the Prophet said: Mâ ana bi Qâri'(I cannot read). This conversation repeated three times until Jibril read verses 1-5 in surah al'Alaq. If iqra' means a call to prayer or worship, as Cuypers explained, this is illogical because the Prophet was worshiping at that time, so there was no need for orders to worship. Besides that, the Prophet's answer indicated that Jibril's command was to read, not to worship. If iqra' interpreted as a call to worship, then the Prophet's answer should also be "I cannot worship," but his answer was "I cannot read" since the word qâri' in the Prophet's answer is ism al-fâ 'il (subject form) from the verb iqra' (to read). In conclusion, that was not a call to prayer or worship since the Prophet was worshipping and was known to be a worship expert.

Nevertheless, on the other hand, this model of interpretation through text structure has a unique feature as an interpretation by the al-Qur'an itself (tafsîr al-Qur'ân bi al-Qur'ân) which the interpretation of one verse refers to the description in other verses. ${ }^{67}$ This interpretation model takes precedence over interpretation using information from the Sunnah, the words of sahâbah and tâbi ${ }^{i} \hat{n}$, interpretation through Arabic language

\footnotetext{
${ }^{66}$ Al-Zarkasyî, al-Burhân, vol. 1, 22-35; al-Qatțân, 75-99; ‘Abd al-Rahmân al-Suyûtịi, al-Itqân Fî̀ 'Ulûm al-Qur'ân, vol. 1 (Mesir: al-Hay'ah al-al-Mishriyyah 'Ammah Li al-Kitâb, 1974), 101-106; Muhammad al-Zurqânî, Manâhil al- 'Irfân Fî 'Ulûm alQur'ân, vol. 1 (Aleppo: Maṭba'ah 'Îsâ al-Bâbi, n.d.), 106-137.

${ }^{67}$ Al- Zarkasyî, vol.2, 175; al- Qațtân, 346.

${ }^{68}$ M. Ridlwan Nasir, Perspektif Baru Metode Tafsir Muqarin dalam Memahami al-Qur'an (Surabaya: Imtiyaz, 2011), 11-12. ${ }^{69}$ Al-Qatțân, 96.
}

rules, and interpretation through other sciences. ${ }^{6}$

Cuypers' interpretation model based on text structure is closely related to the science of occasions ('ilm munâsabât). This science discusses the relationship between sentences in verse, several verses, and chapters. ${ }^{69}$ The aim is to deepen the meaning of verses and determine the unity of its meaning with other verses' meanings.

The achievement of meaning in this interpretation model uses word order indicators around it, or better known as siyâq. In the sciences of the Qur'an, there are three kinds of siyâq. First, indicators in the form of the surah contents from beginning to end; second, indicators in the form of several pieces of conversation in one surah; third, indicators in the form of words in a verse. The three of them affect the interpretation of a word or verse in the Qur'an. ${ }^{70}$

\section{Conclusion}

Based on the point of view of 'ulum alQur'ân, the Semitic Rhetoric analysis method in the study of the qur'anic text structure has many advantages and disadvantages. Among the advantages referred to is the emergence of new interpretations that utilize information in the Qur'an (tafsîr al-Qur'ân bi al-Qur'ân), indicators of word order around it (siyâq), and verse correlation (munâsabât). However, in some instances, such as the interpretation of surah al'Alaq verse 1, Cuypers' interpretation contradicts the narration of asbâb al-nuzûl or the testimony of the Prophet's hadith. Both are compulsoryin the Qur'anic interpretation, according to classical Muslim scholars.

This study found Cuypers' inconsistencies and subjectivity in dividing the texts based on Semitic Rhetoric principles. However, this study also found SRA's influence on the discourse of al-Qur'an's authenticity among orientalists. Those who do not believe in the authenticity of

\footnotetext{
${ }^{70}$ M.Quraish Shihab, 253-257.
} 
the Qur'an, consider its composition to be random and irregular, and study its meaning based on non-Arabic languages, will find 'new opponents' in academia. Thus, Cuypers indirectly affirms the al-Qur'an's authenticity as found in the discourse of 'ulûm al-Qur'ân.

Finally, this article has provided a different perspective from previous research on Semitic Rhetoric in studying the structure of qur'anic text. This perspective has nothing to do with biblical studies, interreligious dialogue, racist theology, or structural linguistics. Nevertheless, it is purely from the Qur'anic sciences formulated by Muslim scholars for a long time. Hopefully, this study could give a brief direction to apply Cuypers' approach properly in analyzing qur'anic structure and then interpret qur'anic text correctly based on its structure.

\section{References}

'Abbas, Fadll Hasan. I'jâz al-Qur'ân al-Karîm. Amman: Dâr al-Nafâis, 2015.

Michel Cuypers, P.F.J. https://www.ideo-cairo. org/en/michel-cuypers-p-f-j-2/. Internet.

Accessed on 24 February 2020.

Asnawi, Aqdi Rofiq. "Penerapan Semitic Rhetoric Analysis (SRA) pada Surah al-Qiyâmah.” Mutawatir: Jurnal Keilmuan Tafsir Hadith 8, no. 1 (2018), 143-169.

Attallah, Halla. Michel Cuypers, The Composition of the Qur'an: Rhetorical Analysis. Translated by Jerry Ryan. London-New York: Bloomsbury Academic, 2015.” Der Islam 95, no. 1 (2018): 211-217.

Bell, Richard. The Qur'ân: Translated, With a Critical Re-arrangement of the Surahs. Edinburgh: T. \& T. Clark, 1939.

Biqâ'̂̂, Ibrâhim bin 'Umar. Nażmu al-Durar fî Tanâsubi al-Âyât wa al-Suwar. Kairo: Dâr al-Kutub al-Islâmî, n. d.

Boisliveau, Anne-Sylvie. "Reviewed Work: Le Festin: Une lecture de la sourate al-Mâ'ida by Michel Cuypers." Journal of Qur'anic Studies 9, no. 1 (2007): 119-23.

Cuypers, Michel. "Semitic Rhetoric as a Key to the Question of the Nazm of the Qur'anic Text”. Journal of Qur'anic Studies 13, no. 1 (2011): 1-24.

. Fî̀ Nazmi al-Qur'ân. Transleted from English, The Composition of the Qur'an: Rhetorical Analysis, by 'Adnân alMuqrânî and Târiq Manzû. Beirut: Dâr al-Masyriq, 2018. . Fî̀ Nazmi Sûrati al-Mâ'idah: Nażmu Âyi al-Qur'ân fì Daw'i Manhaji al-Tahlîl al-Balâghî. Transleted from English, The Banquet: A Reading of the Fifth Sura of the Qur'an, by 'Amr Abd al-'Âṭ̂ S Sâlih. Beirut: Dâr al-Masyriq, 2016.

Douglas, Mary. Thinking in Circles: An Essay on Ring Composition. New Haven and London: Yale University Press, 2007.

Farrin, Raymond. Structure and Qur'anic Interpretation: A Study of Symmetry and Coherence in Islam's Holy Text. Ashland, Oregon: White Cloud Press, 2014.

Hawwâ, Sa'îd. Al-Asâs fì al-Tafsîr. Kairo: Dâr al-Salâm, 1424.

Husayn, Muhammad. al-Mustasyriqûn wa alDirâsât al-Qur'âniyyah. Beirut: Dâr alMuarrikh al-'Arabiy, 1999.

Ibn 'Âsyûr. Al-Tahrîr wa al-Tanwîr. Tunis: alDâr al-Tûnisiyyah li al-Nasyr, 1984.

Idri. Hadis dan Orientalis. Depok: Kencana, 2017.

Izutsu, Toshihiko. God and Man in the Qur'an: Semantics of the Qur'anic Weltanschauung. Petaling Jaya: Islamic Book Trust, 2008.

al-Khațâbî. Bayân I'jâz al-Qur'ân. Kairo: Dâr al-Ma'ârif, 1976.

Meynet, Roland. Rhetorical Analysis: An Introduction to Biblical Rhetoric. Sheffield: Sheffield Academic Press, 1998. Treatise on Biblical Rhetoric. Transl. Leo Arnold. Leiden and Boston: Brill, 2012. 
Mir, Mustansir. Coherence in the Qur'ân. A Study of Islâhî's Concept of Nażm in Taddabur-i Qur'ân. Indianapolis: American Trust Publications, 1986.

Mokrani, Adnane. "Semitic Rhetoric and the Qur'ān: The Scholarship of Michel Cuypers." In New Trends in Qur' anic Studies: Text, Context, and Interpretation. Ed. Mun'im Sirry. Atlanta, Georgia: Lockwood Press, 2019.

al-Mujawwad, Muhammad Yaslam. "Manhaj al-Balâghah al-Sâmiyah fì Dirâsah Bunyat al-Qur'ân al-Karîm," https://tafsir.net/ research/41/mnhj-al-blaght-as-samy-ytfy-drast-bnyt-al-qr-aan-al-krym-drastwsfyt-nqdyh. Internet. Accessed on 24 February 2020.

Nasir, M. Ridlwan. Perspektif Baru Metode Tafsir Muqarin dalam Memahami al-Qur'an. Surabaya: Imtiyaz, 2011.

Netton, Ian Richard. "Towards a Modern Tafsir of Surah al-Kahf: Structure and Semiotics." Journal of Qur'anic Studies 2, no. 1 (2000): 67-87.

al-Qaț̣ân, Mannâ'. Mabâhithun fî̀ 'Ulûm alQur'ân. Kairo: Maktabatu Wahbah, n. d.. al-Râzî, Fakhr al-Dîn. Mafâtîh al-Ghayb. Beirut: Dâr Ihyâ' al-Turâth al-'Arabî, 1420.

Reynolds, Gabriel Said. "Buchbesprechungen." Der Islam 88, No. 2 (2012): 427-434.

Robinson, Neal. Discovering the Qur'an: A Contemporary Approach to a Veiled Text. London: SCM Press, 1996.

Rodwell, J. M. The Koran. New York: Dover Publication, 2005.
Saleh, Walid. "The Etymological Fallacy and Qur'anic Studies: Muhammad, Paradise, and Late Antiquity." In The Qur'an in Context. Ed. Angelika Neuwirth, Nicolai Sinai, Michael Marx. Leiden: Brill, 2010. Shihab, M.Quraish. Kaidah Tafsir. Tangerang: Lentera Hati, 2015.

Sinai, Nicolai. "Review Essay: 'Going Round in Circles': Michel Cuypers, The Composition of the Qur'an: Rhetorical Analysis, and Raymond Farrin, Structure and Qur'anic Interpretation: A Study of Symmetry and Coherence in Islam's Holy Text". Journal of Qur'anic Studies 19, no. 2 (2017): 106-122.

al-Suyûtị̂, 'Abd al-Rahmân. Al-Itqân Fî̀ 'Ulûm al-Qur'ân. Mesir: al-Hay'ah al-alMishriyyah 'Ammah Li al-Kitâb, 1974.

Tilawati, Anis. "Struktur Cincin Dalam al-Qur'an (Perspektif Orientalis-Nicolai Sinai)." Nun: Jurnal Studi al-Qur'an dan Tafsir di Nusantara 4, no. 2 (2018): 51-77.

Wolfensohn, Israel. Târikh al-Lughât alSâmiyyah. Beirut: Dâr al-Qalam, 2016.

Zahniser, Matthias. "Major Transitions and Thematic Borders in Two Long Sûras: Al-Baqara and al-Nisa'." In Literary Structures of Religious Meaning. Ed. Issa Boullata. Richmond: Curzon Press, 2000.

al-Zarkasyî, Badr al-Dîn. Al-Burhân fị̂ 'Ulûm al-Qur'ân. Beirut: Dâr al-Ma'rifah, 1957. al-Zurqânî, Muhammad. Manâhil al-'Irfân Fî 'Ulûm al-Qur'ân. Aleppo: Maṭba'ah 'Îsâ al-Bâbi, n.d. 